\title{
THE DEVELOPMENT OF CENTRAL BANKING AND THE FINANCIAL CRISES IN MEXICO*
}

\author{
VIRGIL Marion BetT \\ University of Michigan
}

The banking system of Mexico was virtually destroyed by the Mexican Revolution (1910-18) and the Mexican money supply was reduced to the insufficient metal currency of the nation. The victorious leaders of the Revolution desired to create a governmentcontrolled central bank as the center of a new banking system. Lack of funds or credit compelled them to delay this action until 1925 .

The Bank of Mexico was established in 1925 and the government purchased a majority of the stock. The Bank functioned, for the first five years of its life, both as a central bank and as a commercial bank. Gradually, thereafter, it evolved into an effective central bank and gave up its commercial banking activities.

The Bank of Mexico gradually increased its strength and its service to the nation largely as a result of its responses to a series of crises in the Mexican economy. Its first response to depression, in the 1930's, was to restrict the expansion of silver money in order to maintain the exchange rate. At the same time the public began to accept Bank of Mexico notes in significant quantities. The Bank was then in a position to employ an expansionary policy based upon note issues. Such a policy was adopted in 1932 and contributed much to the growth of the Mexican economy, but it left the peso largely unsupported on the foreign exchange markets.

In 1935 there was a rise in the price of silver. When this price exceeded seventy-two cents per ounce, Mexican silver coins were worth more as a commodity than as money. Mexico demonetized silver and called it in with the hope of selling it. Bank of Mexico notes became the only legal tender money in Mexico and the position of the Bank was greatly strengthened. With the passage of the law of 1936 the Bank of Mexico became an effective central bank with the power and authority to influence the economy significantly.

In the late 1930's the Mexican government was engaged in a program of development and reform. Land was redistributed to the villages, foreign-held oil properties were expropriated, and the rail-

\footnotetext{
* A dissertation completed at the University of Wisconsin in 1956.
} 
roads were nationalized and turned over to the workers. Schools and roads and other service facilities were built. The Bank of Mexico was engaged in financing these programs, but once more the foreign exchange rate suffered. The reforms discouraged foreign investments and prejudiced foreign markets against Mexican exports so that the Mexican balance of trade could not be maintained.

The development of the Bank of Mexico was largely determined by forces outside itself and often outside of Mexico; forces over which it had little or no control. Gradually, however, its capacity for independent action was increasing.

The Bank of Mexico faced an almost perpetual dilemma; whether to finance economic development at home and allow the peso to fall in value on the foreign market, or to support the peso and restrict the economic development and growth of the country. Between 1925 and 1940 , the peso fell from a rate of about two to the dollar, to almost six to the dollar.

The nation could not escape from this dilemma by banking and monetary policy alone.

Fiscal and foreign trade policy might have been used together with monetary policy to support the value of the peso, and at the same time to assist in the economic development of the country.

Further studies should be made of the operation of the Bank of Mexico after 1940, and of the fiscal and foreign-trade policies of Mexico since the Revolution. 